\title{
Sustainable Development of the Labor Market in the European North of the Russian Federation
}

\author{
Lyudmila Pushkareva ${ }^{1,2}$ and Mikhail Pushkarev ${ }^{2,3, *}$ \\ ${ }^{1}$ North-West Institute of Management, Branch of RANEPA, Sredny prospect VO, 57/43, St. \\ Petersburg, 199178, Russian Federation \\ ${ }^{2}$ Saint Petersburg State University of Architecture and Civil Engineering, 4 Vtoraya \\ Krasnoarmeiskaya, Saint Petersburg, 190005, Russian Federation \\ ${ }^{3}$ Saint-Petersburg State Institute of Technology, 26 Moskovsky prospect, St. Petersburg, 190013, \\ Russian Federation
}

\begin{abstract}
The economy of the European North of the Russian Federation is predominantly based on the use of natural resources. The mining complex remains the leading one in its structure. Its specialization focused on the production of raw materials and the export of products with low added value increases the dependence of the socio-economic situation on the conditions in world commodity and raw materials markets. The economies of the regions under consideration have some common features: the economies are export-oriented. Consequently, the economy depends on world prices for relevant products, conditions in world markets, and a number of political factors. The work revealed a change in the amount of labor force in recent years, assessed structural changes in the economy that affect the dynamics of employment and the level of qualifications. The quality of life of the population in the regions of the European North of Russia is also assessed in this paper.
\end{abstract}

\section{Introduction}

The labor market is characterized by the demand for labor force, the supply of labor force and its price, i.e. wages. The demand for labor force depends on the level of labor productivity, technical equipment of production, and the level of economic activity. The supply is determined by the level of wages, education and qualifications, working conditions, tax system, population migration. The relationship between demand and supply of labor force in the labor market determines the level of employment and manifests itself in the market price of labor force - wages. The price of labor, i.e. wages, is the main source of monetary income for households, and largely determines the quality of life of the population, the level of social prestige and well-being of the employee and his family.

\footnotetext{
${ }^{*}$ Corresponding author: malexpush@bk.ru
} 


\section{Materials and Methods}

The regions of the Far North of the European part of the Russian Federation include the Republic of Karelia, the Komi Republic, the Arkhangelsk Region, the Nenets Autonomous Okrug, and the Murmansk Region. According to the Federal State Statistics Service, the main indicators characterizing the economic potential of the region are the turnover of organizations by type of economic activity in current prices. However, the turnover in current prices in conditions of significant inflation does not allow considering the dynamics of this indicator.

Table 1. The structure of the turnover of the regions of the European North by sectors of the economy, in $\%$.

\begin{tabular}{|c|c|c|c|c|c|c|c|c|c|c|}
\hline Entities & 蹗 & 窇 & 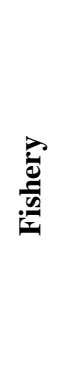 & 葛 & 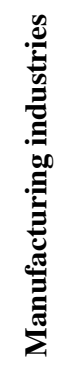 & 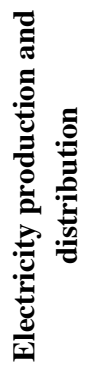 & 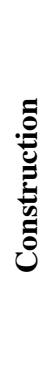 & 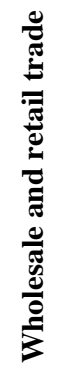 & 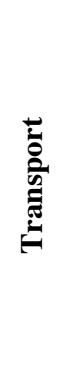 & 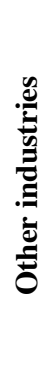 \\
\hline Komi Republic & 100 & 0.9 & - & 39.5 & 21.0 & 6.5 & 5.5 & 3.5 & 22.2 & 0.9 \\
\hline Murmansk region & 100 & 0.3 & 9.2 & 29.2 & 14.5 & 9.5 & 1.5 & 23.1 & 6.7 & 6.0 \\
\hline $\begin{array}{l}\text { Republic of } \\
\text { Karelia }\end{array}$ & 100 & 4.4 & 1.25 & 31.2 & 24.3 & 11.25 & 1.9 & 20.0 & 2.5 & 3.3 \\
\hline NAO & 100 & - & 0.9 & 70.5 & 0.9 & 0.9 & 1.8 & 12.5 & 2.6 & 9.9 \\
\hline 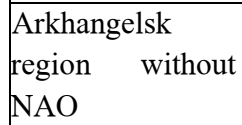 & 100 & 1.6 & 1.5 & 0.5 & 65.1 & 6.5 & 3.7 & 11.4 & 7.7 & 2.0 \\
\hline
\end{tabular}

The structure of the economy of the considered entities has changed insignificantly in recent years and is presented by the data in table 1 [1,2]. So, the turnover of industrial production is $55-60 \%$ of the total turnover. It is usually industrial enterprises that are cityforming, are the "driving force" of the economy.

Let's take a quick look at the economies of each region.

Economy of the Republic of Karelia. The structure of the republic's economy is monoprofile and depends on a small number of enterprises, which in some cases are city-forming. The largest corporations operating on the territory of the republic are engaged in the extraction of raw materials, primary processing or their transportation [3,4].

Economy of the Komi Republic. The Komi industry has a pronounced focus on raw materials. The pace of development of the republic's fuel and energy complex has a major impact on the overall dynamics of industrial production. The timber industry complex, along with the fuel and energy complex, is the basic one in the economy of the republic. The power industry makes a significant contribution to the development of the republic's economy.

The branches of mechanical engineering and metalworking, light, food, printing industries operate. The branches of the mining complex are promising.

The development of oil refining in the Komi Republic is caused by the presence of an extensive market for oil products. The main enterprise of the oil refining industry is LLC LUKOIL-Ukhtaneftepererabotka. The company specializes in the production of motor gasolines, diesel fuel, aviation kerosene, fuel oil, bitumen, vacuum gas oil and other types of products. The depth of oil refining is low. 
The commodity structure of the republic's exports is primarily focused on raw materials and is represented mainly by the products of the mining sector: oil, liquefied gas, coal. Woodworking and pulp and paper products account for a significant share in exports.

Arkhangelsk region. It has a favorable economic and geographical location: year-round navigation and access to international sea routes, as well as the presence of a trunk transport network. An efficient production infrastructure has been created to develop the extraction and processing of mineral resources.

The leading industries in the region are forestry, woodworking and pulp and paper, which provides a significant part of timber harvesting, production of lumber, paper and pulp in Russia. There are three large pulp and paper mills in the region: OJSC Kotlas Pulp and Paper Mill, OJSC Arkhangelsk pulp and paper mill and JSC Solombalsky LDK.

The region is developing the fuel industry, machine building and metalworking, the electric power industry and the food industry (fishery).

The fuel industry is concentrated in the Nenets Autonomous Okrug, which is part of the Arkhangelsk Region. On the territory of the Okrug, on the basis of the development of oil, gas and coal deposits, the Timan-Pechora fuel and energy complex is being formed.

The food industry of the region is represented mainly by the fishing industry. Fish processing is carried out by Arkhangelsk and Pechora (Naryan-Mar) plants.

The region's agriculture is represented by meat and dairy cattle breeding, reindeer breeding, vegetable growing, potato growing, as well as hunting and animal husbandry.

Murmansk region. The economy of the Murmansk region is mainly based on the use of natural resources. The mining complex remains the leading one in its structure. Its specialization focused on the production of raw materials and the export of products with low added value increases the dependence of the socio-economic situation in the region on the conditions in world commodity and raw materials markets.

The preservation of the leading role of the mining complex in the structure of the regional economy is facilitated, firstly, by the implementation of investment projects for the development of new deposits of mineral raw materials (apatite-nepheline, chromite, titanomagnetite, platinoid ores). Secondly, the modernization and application of more productive equipment at the operating enterprises of the complex ensures an increase in labor productivity and makes it possible to compensate for the deterioration in production conditions and the quality of raw materials.

In the fishing industry, the tendencies of the predominant export of products that have not undergone deep processing, as well as the implementation of large volumes of ship repair in foreign ports, persist. The transport complex, like the infrastructure of the region as a whole, is focused on serving the extractive industries and is developing at a moderate pace.

The economies of the regions under consideration have some common features: the economies are export-oriented. Consequently, the economy depends on world prices for relevant products, conditions on world markets, and a number of political factors. Back in 2010-2011, in the administrations of the studied regions, there was a decrease in the number of people, including of the economically active population, which even then led to a decrease in production volumes.

The quality of life of the population. The population of the considered regions is decreasing. The population as of 01.01.2019 compared to 2014: in Karelia - 89.3\%; Komi 95.2\%; in the Arkhangelsk region (without NAO) - 98.0\%; NAO - 106.4\%; in the Murmansk region. - $96.3 \%$.

\section{Results and Discussion}

The decline in population is caused not only by negative natural growth, but also by population outflow. The population leaves the regions under consideration for a number of 
reasons, including the poor quality of living conditions. The living conditions of the population are characterized by indicators of the state of education, housing comfort, life expectancy at birth, infant mortality rate, GRP per capita, etc. These indicators are the most important indicators of the level of socio-economic development of a country or region. The indicators characterizing the provision of amenities to the housing stock are given in table 2 $[5,6]$.

Table 2. Provision of amenities to the housing stock, in \% (2018).

\begin{tabular}{|l|c|c|c|c|c|}
\hline \multicolumn{1}{|c|}{ Regions } & Water supply & Sewerage & Heating & Gas & Hot water \\
\hline RF & 79.5 & 74.5 & 84.3 & 67.5 & 66.2 \\
\hline Karelia & 71.5 & 69.7 & 69.2 & 45.0 & 57.0 \\
\hline Komi & 74.6 & 72.3 & 80.4 & 48.7 & 65.0 \\
\hline Arkhangelsk region & 62.7 & 60.3 & 63.6 & 53.6 & 54.8 \\
\hline NAO & 52.4 & 38.0 & 92.1 & 65.8 & 46.4 \\
\hline Murmansk region & 98.2 & 98.1 & 98.6 & 31.9 & 97.8 \\
\hline
\end{tabular}

From the above data it follows that the provision of amenities to the housing stock in the regions under consideration, except for the Murmansk region, is lower than in Russia as a whole. But the gas supply in the Murmansk region is only $31.9 \%$ (in the Russian Federation - 67.5\%). Even in the Nenets Autonomous Okrug, where hydrocarbon production is underway, the supply of gas and hot water to the housing stock is lower than the all-Russian indicators, and the low availability of water supply and sewerage.

One of the indicators of the quality of life of the population is the indicator of life expectancy at birth [7]. These data are shown in table 3.

Table 3. Life expectancy at birth.

\begin{tabular}{|l|c|c|c|c|c|c|}
\hline \multirow{2}{*}{\multicolumn{1}{|c|}{ Regions }} & \multicolumn{2}{c|}{$\mathbf{2 0 1 7}$} & \multicolumn{2}{c|}{$\mathbf{2 0 1 8}$} & \multicolumn{2}{c|}{$\mathbf{2 0 1 9}$} \\
\cline { 2 - 7 } & man & women & man & women & man & women \\
\hline RF & 64.04 & 75.61 & 64.56 & 75.86 & 65.13 & 76.30 \\
\hline Karelia & 55.03 & 60.85 & 59.83 & 73.41 & 63.17 & 75.05 \\
\hline Komi & 55.82 & 69.46 & 60.73 & 73.32 & 63.22 & 75.39 \\
\hline Arkhangelsk region & No data & No data & 61.77 & 74.59 & 60.22 & 76.30 \\
\hline NAO & 55.59 & 72.43 & 59.15 & 71.36 & 60.22 & 75.21 \\
\hline Murmansk region & 57.65 & 70.46 & 62.69 & 73.90 & 65.15 & 75.26 \\
\hline
\end{tabular}

Preliminary data for 2020 for Russia: life expectancy at birth for men is 65.29 years, for women - 75.49 years. From table 3 it follows that life expectancy at birth for both men and women in 2017-2019 in Russia is higher than in the considered regions. However, in terms of infant mortality rates (the number of deaths per 1000 live births) [8], the situation in the regions under consideration is better than in Russia as a whole.

Table 4. Child mortality rates (per 1000 live births).

\begin{tabular}{|l|c|c|}
\hline \multicolumn{1}{|c|}{ Region } & 2018 year & 2019 year \\
\hline RF & 8.6 & 8.2 \\
\hline Karelia & 7.6 & 6.4 \\
\hline Komi & 5.9 & 6.0 \\
\hline Arkhangelsk region & 7.4 & 7.7 \\
\hline NAO & 2.9 & 2.0 \\
\hline Murmansk region & 6.6 & 6.2 \\
\hline NWFD & 6.2 & 6.2 \\
\hline Saint-Petersburg & 4.5 & 4.6 \\
\hline
\end{tabular}


So, the living conditions of the population in the regions under consideration are worse than in Russia as a whole. This fact and the harsh climatic conditions can explain the outflow of the population.

Wages. It is a known fact that the labor legislation of the Russian Federation provides for benefits and guarantees for workers employed in work in areas with special climatic conditions. For persons working in the Far North and equated localities, one of such guarantees is increased wages with the application of regional coefficients and percentage allowances.

In accordance with Art. 316 of the Labor Code of the Russian Federation, the size of the regional coefficient and the procedure for its application for calculating the wages of employees of organizations located in the districts of the Far North are established by the Government of the Russian Federation. Coefficients depending on the severity of work and living conditions fluctuate mainly in the range from 1.15 to 2 . At the same time, wage conditions cannot be worsened in comparison with those established by labor legislation and other regulatory legal acts containing labor law norms. In the regions under consideration, except for the NAO, the average wage differs slightly from the average wage in Russia as a whole [9]. The relevant information is given in table 5.

Table 5. Average monthly wages (thousand rubles).

\begin{tabular}{|l|c|c|c|c|}
\hline \multicolumn{1}{|c|}{ Regions } & As of 01.01.2018 & December 2018 & January 2019 & June 2019 \\
\hline Karelia & 25.6 & 35.7 & 28.4 & 26.2 \\
\hline Komi region & 34.3 & 49.7 & 38.0 & 34.0 \\
\hline $\begin{array}{l}\text { Arkhangelsk } \\
\text { without NAO }\end{array}$ & 27.3 & 45.6 & 36.3 & 31.4 \\
\hline NAO & 58.4 & 91.6 & 67.5 & 65.7 \\
\hline Murmansk region & 36.4 & 57.8 & 41.4 & 31.4 \\
\hline Russia & & 42.1 & 30.9 & 29.9 \\
\hline
\end{tabular}

In January 2019, the average monthly wage fell sharply compared to December of the previous year and in all regions, except for Karelia, remained higher than the average in Russia. Salaries in June 2019 are significantly lower than in December 2018. However, the comparison of the average wages across the regions of Russia is not entirely legitimate, since prices for food and everyday goods, as well as tariffs for services and works, differ in different regions. Therefore, it is necessary to compare the ratio of wages (incomes) and the size of the minimum wage in the regions of the Russian Federation. This information is presented in table 6 .

Table 6. The ratio of average wages and minimum wage (Q4 2018, \%).

\begin{tabular}{|l|c|c|c|c|}
\hline \multicolumn{1}{|c|}{ Regions } & All population & Employable & Retirees & Rating \\
\hline Karelia & 288 & 327 & 177 & 17 \\
\hline Komi & 342 & 396 & 166 & 15 \\
\hline Arkhangelsk region & 281 & 309 & 145 & 10 \\
\hline NAO & 415 & 491 & 122 & 1 \\
\hline Murmansk region & 403 & 430 & 163 & 12 \\
\hline Russia & 416 & 421 & 166 & - \\
\hline Saint-Petersburg & 543 & 532 & 210 & 37 \\
\hline
\end{tabular}

It follows from the table that, for example, in Karelia, the average salary is 3.27 times higher than the minimum wage, and the pension is only 1.77 times higher than the subsistence level. Only in the Nenets Autonomous Okrug, the average salary exceeds the same indicator for Russia as a whole, but the pension is slightly higher than the minimum wage. 
The highest rates are in St. Petersburg. In St. Petersburg alone, retirees' incomes are 2.1 times higher than the subsistence level, for the entire population incomes exceed the subsistence level by 5.4 times. So, in the northern regions of the European part of the Russian Federation, except for the NAO, the ratio of income and the subsistence level for the considered categories of the population is lower than in Russia as a whole.

The considered table shows data on the average wages in the region. However, there is differentiation, stratification of the population according to the level of income received by different groups of the population, depending on the type of occupation, demographic, professional, territorial factors and other reasons. There are a number of indicators for assessing this differentiation. Most often, the decile coefficient of funds is used, with the help of which the ratio between the total (average) values of the incomes of $10 \%$ of the richest (410) and $10 \%$ of the poorest (41) part of the population is measured. However, in domestic official statistics, a quantile, not a decile, coefficient of funds is given, the value of which is always higher than the quantile, in the calculation of which the population is divided into 5 groups of $20 \%$ each.

The decile coefficient of funds $(\mathrm{Kf})$ is calculated by the formula:

$$
\mathrm{K}_{\mathrm{f}}=\mathrm{S}_{10} / \mathrm{S}_{1} \text {, }
$$

where $\mathrm{S}_{10}$ - total income, which accounts for the $10 \%$ of the population with the highest income;

$\mathrm{S}_{1}$ - total income, which accounts for $10 \%$ of the population with the lowest income.

The quantile coefficient of funds $\left(\mathrm{K}_{\mathrm{f}}\right)$ is calculated by the formula:

$$
\mathrm{K}_{\mathrm{f}}=\mathrm{S}_{5} / \mathrm{S}_{1} \text {, }
$$

where $\mathrm{S}_{5}$ - total income, which accounts for the $20 \%$ of the population with the highest income;

$\mathrm{S}_{1}$ - total income, which accounts for $20 \%$ of the population with the lowest income.

Table 7. Quantile fund coefficients.

\begin{tabular}{|l|c|c|}
\hline \multicolumn{1}{|c|}{ Regions } & $\mathbf{2 0 1 8}$ & $\mathbf{2 0 1 9}$ \\
\hline Republic of Karelia & 11.6 & 11.3 \\
\hline Komi Republic & 17.0 & 16.5 \\
\hline Arkhangelsk region & 13.0 & 12.5 \\
\hline Murmansk region & 13.9 & 14.0 \\
\hline Russia & 16.4 & 16.2 \\
\hline
\end{tabular}

As noted earlier, the quantile coefficient is always lower than the decile coefficient, but only quantile coefficients are given in the regional statistics of the State Statistics Service.

What are the values of the corresponding indicators in developed countries? The lowest decile coefficient is typical for the Scandinavian countries - Denmark, Finland and Sweden (3-4). The population's income polarization is not very high there. In Germany, Austria and France, this coefficient varies from 5 to 7, in the USA it is 15, in Brazil - 39.

According to researchers, the optimal value of the decile coefficient is from 5 to 7 . It is believed that when the decile coefficient reaches 10 , conditions for social unrest appear in the country.

Employment and unemployment. In accordance with the methodology used by the federal state statistics bodies, employed in the economy are considered to be persons who, in the period under review, performed paid work for hire, as well as income-generating selfemployed work, both with and without the involvement of employees. 
Employment rate is the ratio of the employed population of a certain age group to the total population of the corresponding age group, in percent.

Students in educational institutions, retirees and disabled people are counted as unemployed if they did not have a job, were looking for a job and were ready to start it. The unemployment rate (in relation to the ILO standards) is defined as the ratio of the number of unemployed in a certain age group to the number of economically active population in the corresponding age group, in percent.

Table 8 shows the data on the unemployment rate, calculated according to the ILO methodology (Method 1) and according to the data of the employment service institutions (Method 2).

Table 8. Unemployment rate.

\begin{tabular}{|l|c|c|c|c|c|c|}
\hline \multirow{2}{*}{\multicolumn{1}{c|}{ Region }} & \multicolumn{3}{|c|}{ Method 1 } & \multicolumn{3}{c|}{ Method 2 } \\
\cline { 2 - 7 } & $\mathbf{2 0 1 7}$ & $\mathbf{2 0 1 8}$ & $\mathbf{2 0 1 9}$ & $\mathbf{2 0 1 7}$ & $\mathbf{2 0 1 8}$ & $\mathbf{2 0 1 9}$ \\
\hline Republic of Karelia & 8.4 & 7.0 & 8.2 & 2.4 & 2.1 & 1.7 \\
\hline Komi Republic & 8.2 & 6.4 & 7.1 & 2.2 & 2.2 & 1.4 \\
\hline Arkhangelsk region & 5.9 & 5.4 & 6.1 & 1.8 & 1.6 & 2.5 \\
\hline incl. NAO & 8.7 & 6.9 & 7.0 & 2.9 & 1.7 & 1.7 \\
\hline Murmansk region & 8.6 & 7.7 & 7.2 & 2.1 & 1.5 & 1.6 \\
\hline Russia & 6.5 & 5.5 & 5.5 & 1.7 & 2.1 & 1.4 \\
\hline
\end{tabular}

The unemployment rate calculated according to the ILO methodology significantly exceeds the value of the same indicator calculated according to the data of the employment service, since not all citizens looking for work apply to employment service agencies. The unemployment rate calculated according to the employment service for the same periods does not exceed $2 \%$.

Let's consider the dynamics of the number of employed in the above regions of the Russian Federation.

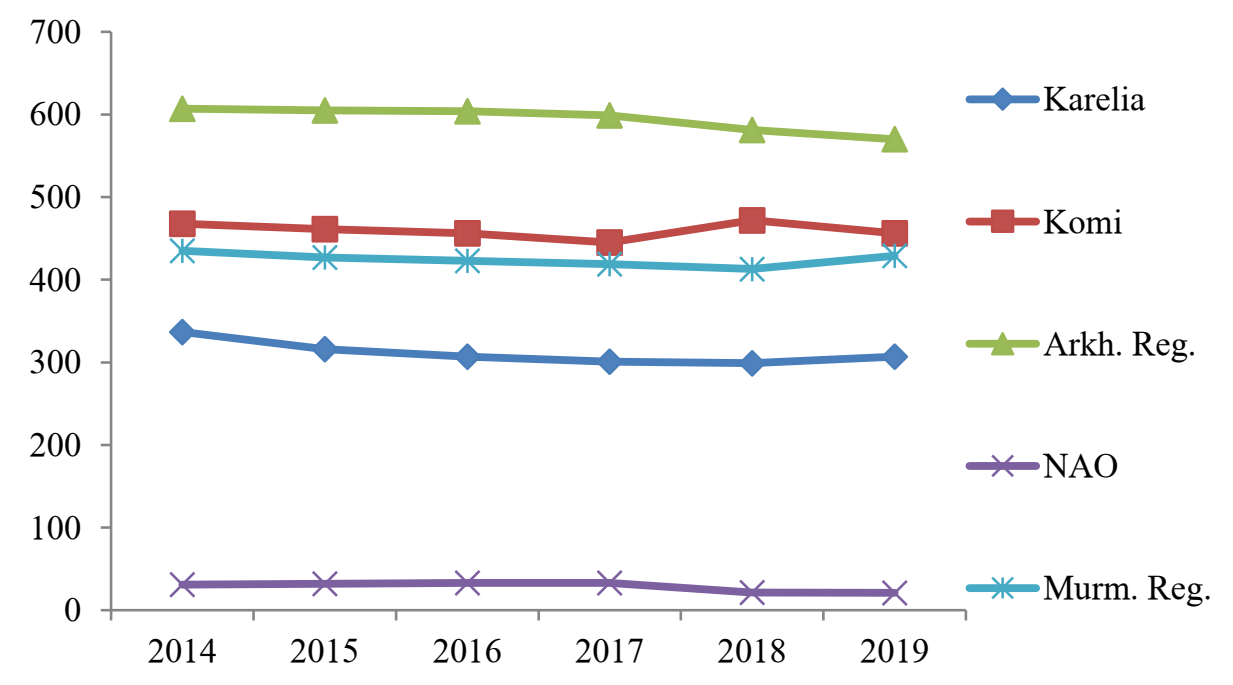

Fig.1. Dynamics of the number of employed.

Data for 2014-2017 is the average annual number of people employed in all sectors of the economy; data for 2018 is the average number for October-December; for 2019 - average data for April-June. 
As follows from Fig. 1, the general trend is a decrease in the number of employed, which can occur under the influence of the following factors: the introduction of new technologies, a decrease in production volumes, a decrease in the population, including the economically active one.

In the situation under consideration, most likely, the last two factors have an impact. It should be noted that the reduction in the number of employees is insignificant. The fact is that at some enterprises, some of the workers are on unpaid leave or work part-time. They are not considered unemployed and the unemployment rates look good.

\section{Conclusions}

Thus, there are economic prerequisites for the development of the northern territories. A special place in the economic policy of the state for the development of northern territories should be given to the quality of life of the population living in these territories, as an economic and social basis for the country's development.

\section{References}

1. Fedulova, O. Y. Voronkova, P. Zhuravlev, et al., Labor productivity and its role in the sustainable development of economy: on the example of a region. Entrepreneurship and Sustainability Issues 7(2), 1059 (2019)

2. A. Trukhachev, Methodology for evaluating the rural tourism potentials: A tool to ensure sustainable development of rural settlements. Sustainability 7(3), 3052-3070 (2015)

3. A. Lialina, Labor market security in the light of external labor migration: new theoretical findings. Entrepreneurship and Sustainability Issues 6(3), 1205 (2019)

4. T. E. Heleniak, The role of attachment to place in migration decisions of the population of the Russian North. Polar Geography 32(1-2), 31-60 (2009)

5. A. While, A. E. Jonas, D. Gibbs, From sustainable development to carbon control: ecostate restructuring and the politics of urban and regional development. Transactions of the Institute of British Geographers 35(1), 76-93 (2010)

6. R. Pomfret, Kazakhstan's economy since independence: Does the oil boom offer a second chance for sustainable development?. Europe-Asia Studies 57(6), 859-876 (2005)

7. V. N. Shchedrin, S. M. Vasilev, A. V. Kolganov, et al. Meliorative institutional environment: The area of state interests. Espacios 39(12), 28 (2018)

8. L. Campling, J. Harrison, B. Richardson, A. Smith, Can labour provisions work beyond the border? Evaluating the effects of EU free trade agreements. International Labour Review 155(3), 357-382 (2016)

9. L. Andrades, F. Dimanche, Destination competitiveness and tourism development in Russia: Issues and challenges. Tourism management 62, 360-376 (2017) 